\title{
Effect of Problem Based Learnig Model on Students Activity and Analytical Skills in Social Studies Project
}

\author{
Andita Nella Pramiftasari ${ }^{1 *}$, Rusijono ${ }^{2}$, Harmanto $^{3}$ \\ Primary Education, Postgraduate, Universitas Negeri Surabaya
}

\begin{abstract}
This study aims to examine the effect of problem-based learning models on the activities of fourth grade elementary school students and analyze the effect of problem-based learning models on the analytical skills of fourth grade elementary school students. Implementation of problem-based learning models requires students to actively work together and analyze the problems being studied so that theoretically the application of this model affects the activities and ability of student analysis. This research is an experimental research design with pretest posttest control group design. The subjects of this study were fourth grade students at SDN Tawangsari 1 Sidoarjo. Data collection techniques through observation of student activity sheets and tests of student analysis skills. The analysis technique used is the $t$ test. In this case the $t$ test was carried out twice, first, to find out the initial conditions of the experimental group and the control group and second to find out the conditions after being treated. The results of the $t$ test activity analysis and the students' analytical skills between the control class and the experimental class before being treated showed no significant difference $\left(t_{\text {count }} 1.222<\right.$ $t_{\text {table }} 2.011$ and sig. 2 tailed value $0.233>0.05$ student activity; $t_{\text {count }} 0.164<t_{\text {table }} 2.011$ and the value of sig. 2 tailed $0.871>0.05$ analytical skills). While the results of the $t$ test after being treated showed that there were significant differences between the experimental group and the control group ( $t_{\text {count }} 3.689>t_{\text {table }} 2.011$ and sig value 2 tailed $0.001<0.05$ student activity; $t_{\text {count }} 2.558>$ table 2.011 and sig. 2 tailed value $0.015<0.05$ analytical skills). In this study, treatment is the only differentiator between the experimental group and the control group, so it can be concluded that there is an effect of the application of problem-based learning models to the students' activity and analytical skills. For teachers who face the problem of low activity and analytical skills students are advised to use problem-based learning models.
\end{abstract}

Keywodrs:- Problem Based Learning Model, Student Activities, Analytical Skill, Social Studies.

\section{INTRODUCTION}

Social studies is an integration of various branches of social sciences such as Sociology, History, Geography, Economics, Politics, Law and Culture. Social science is formulated on the basis of social realities and phenomena which embody an interdisciplinary approach from the aspects and branches of the social sciences. (Trianto, 2007:124). Geography, History, and Anthropology are disciplines that have a high degree of integration. Geography learning provides unanimity of insight with regard to areas, while History provides insights regarding events from various periods. Anthropology includes comparative studies relating to values, beliefs, social structures, economic activities, political organization, expressions and spirituality, technology and cultural property from selected cultures. Political Science and Economics belong to the science of policy in activities related to decision making. Sociology and Social Psychology are behavioral sciences such as the concept of roles, groups, institutions, interaction processes and social control. Concepts like this are intensively used in social sciences and social studies (Trianto, 2007:125). Based on this explanation, it is concluded that social studies is an amalgamation of various branches of social science that study social problems. Sociology and Social Psychology are behavioral sciences such as the concept of roles, groups, institutions, interaction processes and social control. Concepts like this are intensively used in social sciences and social studies (Trianto, 2007: 125). Based on this explanation, it is concluded that social studies is an amalgamation of various branches of social science that study social problems. Sociology and Social Psychology are behavioral sciences such as the concept of roles, groups, institutions, interaction processes and social control. Concepts like this are intensively used in social sciences and social studies (Trianto, 2007: 125). Based on this explanation, it is concluded that IPS is an amalgamation of various branches of social studies that study social problems.

Learning is a learning process which aims to achieve a good process and learning is very closely related to the educational process and better educational outcomes. Without a learning process, of course, the educational process will not have quality. Because basically learning is a process of adding new information and abilities where a process is in the form of ways of preparing a condition so 
that the learning process between teachers and students runs well and is structured so that it can achieve learning objectives. For that, it is necessary to pay attention to the learning process of students in order to gain knowledge from learning activities. The learning or teaching and learning process is a process that is regulated by certain steps, so that implementation achieves the expected results. These steps are usually outlined in the form of a teaching plan (Majid, 2009: 103). This is also in line with several opinions that learning is a combination composed of human, material, facilities, equipment and equipment procedures that influence each other to achieve learning objectives (Daryanto and Tasrial, 2012:154).

Learning objectives are a process of achieving learning in changes that occur in students after participating in learning activities. Learning objectives are statements about the expected learning outcomes (Wena, 2009:5). The existence of more focused learning and more effective and efficient steps to make the goals of the educational process well achieved. In learning activities, students are as subjects and as objects and teaching activities. Therefore, the learning process, if students can actively try, will certainly be able to achieve learning objectives so that the development and improvement of the learning system is an effort that is considered appropriate and able to improve learning.

Efforts to achieve the expected learning objectives, in the implementation of teacher learning are expected to use the right learning model. The use of models in learning activities is very necessary because to facilitate the learning process so that it can achieve optimal results. Without a clear model, the learning process will not be directed so that the learning objectives that have been set are difficult to achieve optimally. In other words, it cannot take place effectively and efficiently. The problem-based learning approach deals with the use of intelligence from within a person in a group to solve a problem that is meaningful, relevant, and factual.

Based on the observations of researchers during the fourth grade learning process at elementary school of Tawangsari 1 Sidoarjo, material on social, economic, cultural and religious diversity in the local province and its relationship with spatial characteristics, learning is still conventional in nature where teachers are more active than students. Students only listen, take notes and do assignments individually. Whereas in the 2013 curriculum students must be active rather than teachers. Students actively ask questions, answer questions, discuss with friends and ask opinions. The teacher is only a facilitator during learning.

Giving assignments individually is also felt to be difficult for students to complete. The time required is longer and the students' answers are also not satisfactory. Especially in the material about solving a problem in Social Sciences lessons, students have difficulty analyzing problems and solving problems. This is not in accordance with the goals of Social Science education, namely to develop the potential of students to be sensitive to social problems, to have a positive mental attitude towards improving all existing gaps, and to be skilled at overcoming problems themselves and society (Trianto, 2007: 128). The difficulty in learning the material is due to the monotonous and meaningless learning concept, so the students' lack of interest and ability to understand the material. One of the efforts that can be done by looking at these problems, it is necessary to have a model that can make students learn actively and be involved in a model that can make students learn to be actively involved in the learning process. One of the appropriate learning models is the problem-based learning model. The use of this learning model is expected to motivate students to improve their ability to analyze and achieve interaction between teachers and students as well as students and students.

Margetson (in Rusman, 2012:230) argues that problem-based learning improves the development of learning skills in an open, reflective, critical, and active learning mindset. Problem-based learning better facilitates successful problem solving, communication, group work and interpersonal skills than other approaches. Duch, Allen and White in (Afcariono, 2008:65) state that problem-based learning improves critical and analytical thinking and solving problems in real life. Researchers chose a problembased learning model because it guides students to learn effectively, besides being able to train and develop the potential of students who have been personally owned by each, are able to involve maximally in finding and understanding a concept through physical, and able to reach every student learning style. In addition, the problem-based learning model is easy to develop because this type is simple to apply with other types. The problem-based learning model is defined as learning that is obtained through a process toward understanding the resolution of a problem where the focus is on student learning and not on teacher teaching (Huda, 2014:271). Learning model that is oriented towards constructivism theoretical framework. In the problem-based learning model, the focus of learning is on the selected problem so that students not only learn concepts related to problems but also scientific methods to solve these problems (Ngalimun, 2016:119). Learning strategies with problem-based learning models offer students freedom in the learning process. For this reason, students are expected to be involved in the learning process to identify problems collecting data, and use the data for problem solving (Rusmono, 2012:74).

Learning activities at school should take place based on the abilities, interests, needs and needs of students. The aim is to develop study skills, independent learning skills, independent learning and problem-solving skills. Teachers in every lesson should provide motivation and use approaches, strategies, models, and learning methods that can make it easier for students to understand the material being taught. Selection of a model is necessary, because in the use of the right learning model it can encourage the growth of student pleasure in lessons, foster and increase motivation in doing assignments, make it easy for students 
to understand learning material so that it can affect their grades or learning outcomes to increase and better.

The objectives of this study are (1) Describe the differences in student learning activities in social science subjects in fourth grade elementary schools in the learning process between classes using problem-based learning models and classes using conventional learning, and (2) examining the effect of problem-based learning models on students' analytical skills in their eyes social science lessons in elementary school

\section{THEORETICAL FRAMEWORK}

\section{$>$ Social Studies}

According to Somantri (Sapriya, 2009:11) social studies is a simplification of the social sciences and humanities disciplines, as well as basic human activities that are presented scientifically and pedagogically for educational purposes. According to Nasution (in Suhanadji and Waspodo, 2003:4) social studies is a lesson from a combination of a number of social subjects. social studies in elementary schools aims to prepare students to master knowledge, skills, attitudes and values (Sapriya in Nupiksani, 2015:14). According to Gunansyah (2015:3) social studies education is a combination of social studies concepts with educational concepts that are studied and developed systematically, psychologically and functionally according to the level of cognitive, moral and social development of students.

Learning in elementary schools has several objectives in it, namely knowledge as a stage to recognize themselves and the provision of students to interact with the surrounding environment as social beings. Skills as a thought process in dealing with circumstances contained in social interactions, attitudes as a form of behavior and behavior, and values as a form of self-implementation in the community environment and the results obtained from the community as a result of their interactions.

The categories of goals already mentioned, the main objectives to develop from education social Sciences namely the self-development of students as individuals who are intended to know themselves and be able to become good citizens by studying the conditions of the community in the surrounding environment, having the ability to communicate with the community in the environment and observing and studying norms or rules and habits apply in society.

\section{> Problem Based Learning Model}

Guru memilih model pembelajaran yang meningkatkan keaktifan dan semangat siswa dalam pembelajaran. Salah satu model pembelajaran yang meningkatkan berpikir siswa yaitu pembelajaran berbasis masalah. Pembelajaran berbasis masalah menurut Sanjaya (Sunaryo, 2014:43) yaitu pembelajaran yang menekankan pada pemecahan masalah secara ilmiah. Pada pelaksanaannya siswa berkelompok dan berdiskusi untuk menyelesaikan masalah. Margetson (dalam Rusman,
2012:230) menjelaskan bahwa pembelajaran berbasis masalah meningkatkan perkembangan keterampilan berpikir siswa. Pembelajaran berbasis masalah memfasilitasi siswa untuk memecahkan masalah dan keterampilan interpersonal lebih baik daripada model pembelajaran lain. Dapat disimpulkan bahwa pembelajaran berbasis masalah merupakan model pembelajaran yang meningkatkan keterampilan berpikir siswa melalui pemecahan masalah dalam kelompok.

The teacher chooses a learning model that increases student activity and enthusiasm in learning. One learning model that improves student thinking is problem-based learning. According to Sanjaya (Sunaryo, 2014:43), problem-based learning is learning that emphasizes scientific problem solving. In practice, students work in groups and discuss problems to solve. Margetson (in Rusman, 2012:230) explains that problem-based learning improves the development of students' thinking skills. Problem-based learning facilitates students to solve problems and interpersonal skills better than other learning models.

Trianto (2010:94) explains the goal of problem-based learning, which is to help students develop thinking skills and problem-solving skills, then learn the role of authentic adults. Problem-based learning has implications: a) encouraging cooperation, b) encouraging observation and dialogue with others, c) involving students in investigating their own choices so that students can explain real-world phenomena independently, become independent learners in solving problems with teacher direction .

Problem design in problem-based learning includes (1) the root of the problem design, namely the existing reallife problems. Teacher education is able to fill the gap between theory and practice in education. In this model, the problem posed must be able to arouse student understanding and the desire to solve problems with gaps that students have; (2) determine problem-based learning objectives, namely a way to use problems to attract student motivation in learning. The successful implementation of problem-based learning is based on the selection, design and development of the problems to be presented. According to Rusman (2012:238) problem-based learning objectives are mastery of the content of the lesson and the skills to solve the problems presented; (3) design problems, that is, the complexity of the problem depends on the student's background and the student's profile. According to Rusman (2012:238), problem design has characteristics including characteristics, context, presentation, sources and learning environment. The teacher's role in implementing problem-based learning is (1) preparing students' thinking tools; (2) emphasizes cooperative learning; (3) facilitating small group learning in problem-based learning; (4) implement problem-based learning 


\section{Student Activities}

According to Hosnan (2014:183) learning is an activity that is carried out psychologically and physiologically. Another opinion was expressed by Sugono (2008:32) that activity means activity. This opinion was strengthened by Suhana (2014:21). Learning activities are a process of learning activities that involve all psychophysical aspects of students both physically and spiritually so that the acceleration of behavior changes can occur appropriately, quickly, easily, correctly, and is related to cognitive, affective and psycho-motor aspects.

The two are interconnected so as to produce optimal learning activities. In learning, activity is needed. Student activity during the teaching and learning process is an indication of student motivation to learn. Students are said to be active when there are behaviors such as frequently asking questions, doing assignments, being able to answer questions, and so on.Gagne and Brings (in Yamin, 2007: 84) factors that can encourage activity, namely: (a) motivation; (b) learning objectives; (c) learning competencies; (d) problems / topics; (e) working instructions; (f) participation; (g) feedback; and (h) the final test.

\section{Analysis Ability}

Anderson (2008:33) states that analyze-break material into its constituent parts and determine how the parts relate to one another and to an overall structure or purpose. Analysis is breaking matter into its elemental parts and determining how these parts relate to one another and to the overall structure or purpose.

According to Durotulaila et al (2014:68) the ability to analyze is to describe the material according to the smallest part and to be able to understand the relationship of each part to solve a problem. Meanwhile, according to Firdaus (2016) problem analysis is a study to find out the causes of problems, as well as alternative solutions to problems. From the three explanations, it can be concluded that analysis is the ability to decompose a material or problem into smaller parts so that it can easily know the relationship of each part and easily find solutions to problems.

\section{RESEARCH METHOD}

This type of research applied to this research is experimental research. According to Sugiyono (2016:72) experimental research can be interpreted as a research method used to find the effect of certain treatments on others under controlled conditions. This study aims to determine the effect of problem-based learning model treatment on students' activities and analytical skills in social studies subjects. The main objective of this study is to compare student activity and students' analytical skills in the experimental class and the control class. The design of this study was a quasi-experimental study with a nonequivalent control group design.

\begin{tabular}{|c|c|c|c|}
\hline Class & Pretest & Treatment & Posttest \\
\hline Experiment & $\mathrm{O}_{1}$ & $\mathrm{X}$ & $\mathrm{O}_{2}$ \\
\hline Control & $\mathrm{O}_{3}$ & $\mathrm{C}$ & $\mathrm{O}_{4}$ \\
\hline
\end{tabular}

Table 1:- Nonequivalent Control Group Design

Information:

$\mathrm{O}_{1} \quad$ : Initial test in the experiment group

$\mathrm{O}_{2} \quad$ : The final test in the experiment group

$\mathrm{X} \quad$ : Problem based learning model

$\mathrm{C} \quad$ : Direct learning model

$\mathrm{O}_{3} \quad$ : Initial test in the control group

$\mathrm{O}_{4} \quad$ : The final test in the control group

The research subjects were students of class IV A as the control class totaling 20 students and class IV $\mathrm{C}$ as the experimental class totaling 20 students. Collecting data in research using observation sheets and tests. The observation sheet is used to observe student activities during the learning process in both the experimental class and the control class, while the test is used to measure students' analytical skills after receiving treatment.

Before to data analysis, the researcher conducted a validity test and a reliability test aimed at determining the feasibility of an instrument. The data collected from the results of the distribution of the instruments were then analyzed using the normality test and the homogeneity test. After that, the hypothesis is tested.

\section{RESULTS}

Before being used for research, the instruments used were validated first by an expert validator. The validation results by the validator are presented below.

\begin{tabular}{|c|c|c|c|c|c|}
\hline \multirow{2}{*}{ No. } & \multirow{2}{*}{ Validated Instrument } & \multicolumn{2}{|c|}{ Score } & \multirow{2}{*}{ Predicate } \\
\cline { 3 - 5 } & & V1 & V2 & Average & \\
\hline 1. & Syllabus & 3,55 & 3,36 & 3,45 & valid \\
\hline 2. & Lesson plan & 3,65 & 3,45 & 3,55 & very valid \\
\hline 3. & Teaching Materials & 3,67 & 3,53 & 3,6 & very valid \\
\hline 4. & Student activity observation instruments & 3,56 & 3,56 & 3,56 & very valid \\
\hline 5. & Test students analytical skill instrument & 3,5 & 3,67 & 3,58 & very valid \\
\hline
\end{tabular}

Table 2:- Results of the Validation of Research Instruments by Expert Validators

Source: Author processed data, 2020 
ISSN No:-2456-2165

\begin{tabular}{|c|c|}
\hline Validation Score Range & Category \\
\hline $3,6 \leq \mathrm{P} \leq 4,0$ & very valid \\
\hline $2,6 \leq \mathrm{P} \leq 3,5$ & valid \\
\hline $1,6 \leq \mathrm{P} \leq 2,5$ & less lalid \\
\hline $1,0 \leq \mathrm{P} \leq 1,5$ & invalid \\
\hline
\end{tabular}

Table 3:- Criteria for Assessment of Learning Devices

Information:

$\mathrm{P} \quad$ : Passing Grade (average value)

Researchers tested the feasibility of research instruments before analyzing the research data. At this stage, 7 test items are

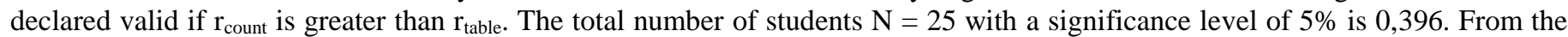
data analysis using SPSS version 21, it was found that all test instruments were declared valid

\begin{tabular}{|c|c|c|c|}
\hline Aspect & r count & r table & Information \\
\hline Item No. 1 & 0,723 & 0,396 & Valid \\
\hline Item No. 2 & 0,800 & 0,396 & Valid \\
\hline Item No. 3 & 0,649 & 0,396 & Valid \\
\hline Item No. 4 & 0,620 & 0,396 & Valid \\
\hline Item No. 5 & 0,768 & 0,396 & Valid \\
\hline Item No. 6 & 0,723 & 0,396 & Valid \\
\hline Item No. 7 & 0,800 & 0,396 & Valid \\
\hline
\end{tabular}

Table 4:- Validity Test Result

Source: Author processed data, 2020

After testing the validity of the research instrument, the next step was to test the reliability of the test instrument. This is to find out whether the test instrument is reliable or not. Reliability testing in research instruments that have been trusted and reliable will produce reliable data too. In this study, the reliability test was carried out to test the test instrument using the alpha cronbach's formula through the SPSS version 21 data processing program. The results of the reliability of language development are as follows.

\begin{tabular}{|c|c|}
\hline Cronbach's Alpha & N of Items \\
\hline, 848 & 7 \\
\hline
\end{tabular}

Table 5:- Reliability Test Results

Source: SPSS output

Based on the table above, the results obtained from the test instrument reliability test show the reliability of 0.848 . Based on the clarification table of the reliability coefficient (Ruseffendi, 2005: 50) it is known that the reliability test results of the social skills instrument have a high reliability level with the criteria of $0,80 \leq 0,848 \leq 1,00$ so that this instrument can be used in research.

The normality test is used to test whether the data is normally distributed or not. The normality test used the KolmogorovSmirnov formula with a significance level of 0.05 or $5 \%$, using SPSS.

\begin{tabular}{|c|c|c|c|c|}
\hline Variabel & Class & Score Significance & Level & Information \\
\hline Student activity (pretes) & \multirow{2}{*}{ Control } & 0,468 & 0,05 & Normal \\
\cline { 4 - 5 } Student activity (posttest) & & 0,359 & 0,05 & Normal \\
\hline Student activity (pretes) & \multirow{2}{*}{ Experiment } & 0,364 & 0,05 & Normal \\
\cline { 4 - 5 } Student activity (posttest) & \multirow{2}{*}{ Control } & 0,594 & 0,05 & Normal \\
\hline Analysis Ability (Pretest) & & 0,949 & 0,05 & Normal \\
\hline Analysis Ability (Posttest) & \multirow{2}{*}{ Experiment } & 0,999 & 0,05 & Normal \\
\cline { 4 - 5 } Analysis Ability (Pretest) & & 0,920 & 0,05 & Normal \\
\hline Analysis Ability (Posttest) & & 0,976 & Normal \\
\hline
\end{tabular}

Table 6:- Normality Test Results

Source: Author processed data, 2020 
ISSN No:-2456-2165

The normality test used the Kolmogorov-Smirnov formula with a significance level of $5 \%$, namely 0,05 . If the significance value $<0,05$, the conclusion is that the data are not normally distributed. However, if the significance value is $>0,05$, the data is normally distributed. Based on table 6 above, all variables have a value of more than 0,05 , so it can be stated that all research variables have a normal distribution.

This homogeneity test is carried out to test the similarity of several different samples. This homogeneity test uses the Oneway Anova test using SPSS with the criteria if the probability is $(\mathrm{P}>0,05)$ the sample is homogeneous, whereas if the probability is $(\mathrm{P}<0,05)$ the sample is not homogeneous.

\begin{tabular}{|c|c|c|c|c|}
\hline Variable & Class & $\begin{array}{c}\text { Score } \\
\text { Significance }\end{array}$ & Level & Information \\
\hline \multirow{2}{*}{ Student activity (pretest) } & Kontrol & \multirow{2}{*}{0,297} & \multirow{2}{*}{0,05} & \multirow{2}{*}{ Homogeneous } \\
\hline & Eksperimen & & & \\
\hline \multirow{2}{*}{ Student activity (posttest) } & Kontrol & \multirow{2}{*}{0,326} & \multirow{2}{*}{0,05} & \multirow{2}{*}{ Homogeneous } \\
\hline & Eksperimen & & & \\
\hline \multirow{2}{*}{ Analysis Ability (Pretest) } & Kontrol & \multirow{2}{*}{0,947} & \multirow{2}{*}{0,05} & \multirow{2}{*}{ Homogeneous } \\
\hline & Eksperimen & & & \\
\hline \multirow{2}{*}{ Analysis Ability (Posttest) } & Kontrol & \multirow{2}{*}{0,502} & \multirow{2}{*}{0,05} & \multirow{2}{*}{ Homogeneous } \\
\hline & Eksperimen & & & \\
\hline
\end{tabular}

Table 7:- Homogeneity Test Results

Source: Author processed data, 2020

Table 7 is the homogeneity test data using the $5 \%$ significance level, namely 0,05 . The conclusion is, if the significance value is $<0,05$, the variant of the data group is not homogeneous, and if the significance value is $>0,05$, the variant of the data group is homogeneous. Based on the table above, all variables have homogeneous data variants

Hypothesis testing in order to answer the problem formulations and hypotheses proposed in this study. Hypothesis testing used in this study is to use the $t$ test.The $t$ test is needed to partially test the significance level between each independent variable's influence on the dependent variable.

\begin{tabular}{|c|c|c|c|c|}
\hline Variable & $\mathbf{T}$ & Df & Sig. (2-tailed) & Description \\
\hline Student activity & 3,689 & 38 & 0,001 & $\mathrm{H}_{1}$ accepted \\
\hline Student analytical ability & 2,558 & 38 & 0,015 & $\mathrm{H}_{2}$ accepted \\
\hline
\end{tabular}

Table 8:- Hypothesis Test

Source: Author processed data, 2020

The results of the analysis in table 8 show that the results of the analysis showed that the sig 2 tailed was $0,001<\alpha(0,05)$ with $t_{\text {count }}>t_{\text {table }}$ of $(3,689>2,024)$. Thus, it can be stated that $\mathrm{H}_{1}$ is accepted. The students' analytical skills obtained the results of the analysis with a sig 2 tailed value of $0,015<\alpha(0,05)$ with $t_{\text {count }}>t_{\text {table }}$ of $(2,558>$ $2,024)$, it can be stated that $\mathrm{H}_{2}$ is accepted.

Based on the data analysis above, the conclusion that can be drawn is that there is a significant difference between the scores in the control class and the scores in the experimental class. This significant difference is evidenced by the t-test analysis so that treatment using a problembased learning model can affect the activities and analytical skills of fourth grade students in social studies subjects in elementary schools.

\section{DISCUSSION}

The Effect of Problem Based Learning Model on Student Activities

The problem-based learning model is more effectively used in learning, this is in accordance with Nur (2011:33) who states that the problem-based learning model demands student activity when compared to using conventional learning models. The benefit of raising a problem at the beginning of learning can trigger student thinking so that students will try to solve it scientifically. Margetson (in Rusman, 2012:230) explains that problem-based learning improves the development of students' thinking skills. Problem-based learning facilitates students to solve problems and interpersonal skills better than other learning models. In addition, it creates interactions between students and teachers and fosters the courage of students to speak up to express their opinions. 
Learning is an activity that can be done psychologically or physiologically (Hosnan, 2014:183). Activities that are psychological in nature, namely activities such as mental processes, for example thinking, understanding, concluding, listening, examining, comparing, differentiating, expressing, analyzing, and so on. While activities that are physiological, namely activities that are the process of application, for example doing experiments, exercises, practice, making products, appreciation and so on. Another opinion is expressed by Sardiman (2014:103) that in learning there needs to be activity, because in principle learning is doing or learning by doing. Activities are principles or principles that are very important in learning interactions. According to Nur \& Wikandari (2000:1) learning is more than just remembering. A student to truly understand and be able to apply knowledge, they must work hard to solve problems, find things and always be in touch with ideas or ideas. Intellectual development of students occurs when students are faced with interesting and challenging experiences in life that occur in the environment.

The learning process that is expected to occur according to Aunurrahman (2013) is a process that can develop students' potentials in a comprehensive and integrated manner. The development of individual dimensions partially will not be able to support the optimization of potential development of students as expected. For this reason, in the learning process the teacher is not only required to convey subject matter but must be able to actualize its strategic role in an effort to shape student character through developing personality and prevailing values.

In group discussions, cooperation between students is inseparable. Characteristics of cooperation groups according to Johnson \& Johnson (1991:34) are (1) positive interdependence, (2) face-to-face promotive interaction, (3) individual accountability and personal responsibility, (4) interpersonal and small group skills, (5) ) group processing. So it can be seen that there are components inherent in cooperation, namely positive interdependence among individuals in the group to achieve goals, face-to-face interactions that increase success with each other among individuals in the group, the existence of individual personal accountability and responsibility, the existence of interpersonal communication skills and small groups, as well as the skills to work in groups. Cooperation in groups is more practical, meaning that the level of cooperation abilities that students have will be seen directly in the practical behavior of students in groups. Students can be said to have cooperative skills if students demonstrate the following behaviors: (1) consciously, without being ordered or pushed around, helping to identify group goals, and expressing commitment and giving their role actively to work towards group goals, ( 2) show or demonstrate effective interpersonal relationship cooperation, (3) contribute to the maintenance of group continuity.
Group collaboration in class has the main objective of making students actively involved in the learning process. Grouping students in pairs or small groups increases their chances of being involved. Students will feel less pressure when asked to complete an assignment with a peer than if they complete it themselves. Collaboration or learning together is a team (group) process where members support and rely on each other to achieve a consensus. Cooperation has the following objectives, namely: (a) providing opinions about problems with questions, insights and solutions in groups, (b) exchanging ideas between one friend and another so that friends who previously did not know will know,

A teacher at school not only acts as a conveyor of subject matter (transfer of knowledge), but also must be able to portray himself as a social worker, student and scientist, parent, role model seeker, and security seeker (Usman, 2002). Teachers have responsibilities from a professional perspective. This is in accordance with the opinion of Simsek (2017) which states that a teacher must have various competences and professional skills. A teacher must have skills in managing his class. In addition, the skills a teacher must have are skills to evaluate and assess their students. Furthermore, the teacher can develop various learning materials with various learning media.

This research is relevant to the results of research by Parwata (2009). This study identifies that there is an effect of problem-based learning models on student learning motivation. The results of this study are in line with the results of research conducted by Farida (2010), which states that the problem-based learning model can increase student motivation and student learning activities better than the direct teaching model. When carrying out student activities, a driver is needed that is able to actualize the course of learning. Gagne and Brings (in Yamin, 2007:84) factors that can encourage activity, namely: (a) motivation; (b) Learning objectives; (c) Learning competence; (4) Problems / topics; (5) working instructions; (6) Participation; (7) Feedback; and (8) the final test.

\section{$>$ The Effect of Problem Based Learning Model on Students' Analysis Ability}

Trianto (2010: 94) suggests that the goal of problembased learning is to help students develop thinking skills and problem-solving skills, then learn the role of authentic adults. Problem-based learning has implications: a) encouraging cooperation, b) encouraging observation and dialogue with others, and c) involving students in investigating their own choices so that students can explain real-world phenomena independently, become independent learners in solving problems with directions teacher. The same thing was echoed by Ibrahim and Nur (2000: 19) regarding Vigotsky's learning theory that believes that social interaction with friends spurs the formation of new ideas and enriches students' intellectual development. 
Problems can encourage seriousness, inquiry, and think in a meaningful and very strong (powerful) way. Education requires new perspectives in finding various problems and ways of looking at problems. Various breakthroughs in science and technology are the result of interest in the problem. In general, education begins with an interest in problems, continues with problem determination, and uses various dimensions of thinking. In solving problems that exist in the real world, we need to realize that all cognitive processes and mental activities are involved. The brain works with a certain cycle and literacy of thinking systematically, systemically, general analysis, and divergent (Rusman, 2014: 213). The 21st century is marked by high connectivity due to inseparable realities. Issues that exist in the real world are cross-disciplined and involve interrelated perspectives. We need a broad view of things and a mixture of each of the different interrelated basic knowledge.

The results above indicate that student learning outcomes have increased by using problem-based learning models. In the learning process, learning outcomes are important to determine the achievement of predetermined competencies. This is in line with the opinion of Jihad and Haris (2012: 15) that learning outcomes are changes in student behavior in real terms after a teaching and learning process is carried out in accordance with the learning objectives. So, students are expected to be able to achieve the learning objectives and competencies that have been determined in a teaching and learning process in order to achieve the main goals of an education as stated in Law no.

The findings in this study are in line with Cloud's (2017) research which states that students who are treated with problem-based learning are significantly better than students treated with conventional learning models. This is in accordance with research conducted by Hallinger and Bridges (2016) which mentions eight different studies which mostly concluded that the use of problem-based learning allows students to achieve better learning outcomes. Another study was conducted by Bilhuda et al (2017: 439) which states that learning models can improve learning outcomes for elementary school students.

According to Anderson \& David (2015), one of the higher-order thinking skills is the ability to analyze. Analyzing is a process which involves the process of breaking matter down into smaller parts and determining how the relationships are between the parts and between each part and the structure of the whole. According to Atika et al., (2012) analytical skills are the initial abilities that must be developed to achieve critical thinking skills. Analytical skills have a role in solving various problems in everyday life.

The cause of differences in the results of students' analytical abilities applying problem-based learning models with conventional learning models is because in the experimental class students not only form information from a subject matter that they know beforehand, but are also accustomed to building systematic relationships between pieces of information by identifying important elements and determine the structure formed during the learning process. Whereas in the control class, students only understand the information described by the teacher. This is in line with the results of research by Dostal (2015) which states that when students can find coherence between what is known and what is not known then connect them so that in the end they find a point of view that can solve the problem. Another reason put forward by Yulianti et al (2018: 92) that the value of student learning outcomes in the experimental class is better is good cooperation by group members. All group members have responsibilities, opinions, solutions and insights conveyed by each group member. The positive influence of problem-based learning models on students' analytical thinking skills is because this learning model makes it easier for students to understand learning material because in the learning process students get the concepts of learning material meaningfully and are motivated to understand the material. solutions and insights conveyed by each group member. The positive influence of problem-based learning models on students' analytical thinking skills is because this learning model makes it easier for students to understand learning material because in the learning process students get the concepts of learning material meaningfully and are motivated to understand the material. solutions and insights conveyed by each group member. The positive influence of problem-based learning models on students' analytical thinking skills is because this learning model makes it easier for students to understand the learning material because in the learning process students get the concepts of learning material in a meaningful way and are motivated to understand the material.

The purpose of problem-based learning is to help students develop thinking skills, problem solving, intellectual skills, learn about various adult roles through their involvement in real experiences or simulations, and become independent learning (Nurhadi et al., 2004: 58). In problem-based learning, before starting the teaching and learning process in the classroom, students are first asked to observe a phenomenon or problem given by the teacher. Then students are asked to record the problems that arise. After that, the teacher's job is to stimulate students to think critically in solving an existing problem. The teacher's job is to direct a different perspective from them.

One of the characteristics of students that must be considered in selecting and implementing a learning model and the achievement of learning outcomes is the difference in students' cognitive styles. Cognitive style is closely related to the ways and attitudes of students in learning which can affect their learning achievement. Each cognitive style has advantages and disadvantages in achieving learning outcomes. Problem-based learning model is a learning model based on constructivism philosophy. Problem-based learning models are designed based on real life problems that are ill-structured, open, and ambiguous (Forgaty, 1997). Problem-based learning models can arouse student interest, real, and suitable for building intellectual abilities. Hasting (in Arnyana, 2005) said that the problem- 
based learning model can improve students' understanding of the material being studied, the ability to solve problems, and the skills to apply concepts.

\section{CONCLUSIONS AND SUGGESTIONS}

\section{A. Conclusion}

The results of the t-test analysis of student activity (posttest) in the control and experimental classes obtained the $t_{\text {count }}(3,689)>t_{\text {table }}(2,024)$ with $d f=38$ and $a$ significance level of $5 \%(0,05)$. That is, there is a significant difference in student activity between the experimental class and the control class, so it can be concluded that there are differences in activity between students whose learning applies the problem-based learning model and students whose learning applies the conventional model.

The results of the t-test analysis of the analytical ability between the experimental class and the control class were analyzed twice. First, the results of the t-test analysis of the students' pretest analysis abilities between the experimental class and the control class obtained the value of $\mathrm{t}_{\text {count }}(0,164)<\mathrm{t}_{\text {table }}(2,024)$ with $\mathrm{df}=38$ and $\mathrm{a}$ significance level of $5 \%(0,05)$. That is, there is no significant difference in students' analytical skills at the pretest between the experimental class and the control class. Second, the results of the t-test analysis of students' posttest analysis abilities between the experimental class and the control class obtained $t_{\text {count }}(2,558)>t_{\text {table }}(2,024)$ with $\mathrm{df}=38$ and a significance level of $5 \%(0,05)$. That is, there is a significant difference in students' analytical abilities in the posttest between the experimental class and the control class.

\section{B. Suggestion}

The application of problem-based learning in learning requires good readiness from the teacher who must act as a facilitator as well as a guide. Teachers are required to fully understand each part and the concept of problem-based learning and become mediators who are able to stimulate students' thinking skills. In addition, students must also be ready to be actively involved in learning. The problems discussed must be those that are relevant to the demands of life at the present and in the future. Problem-based learning can take advantage of e-learning facilities collaboratively in the problem solving process.

Based on the learning outcomes and analytical skills that have been achieved by using problem-based learning models, this model can help students solve problems with various alternatives, so that students can better understand the learning material. The principal as the party who plays an important role in developing and evaluating the ability of teachers in carrying out the learning process, should always motivate teachers to use this model as an alternative in learning to be able to increase student activity and problem analysis skills so that an active learning will be realized, effective and fun

\section{REFERENCES}

[1]. Afcariono, Muchamad. (2008). Penerapan Pembelajaran Berbasis Masalah untuk Meningkatkan Kemampuan Berpikir Siswa pada Mata Pelajaran Biologi. Jurnal Pendidikan Inovatif, 3 (2), 65-68.

[2]. Anderson, T. (2008). The Theory and Practice of Online Learning. Second Edition. Athabasca University: AU Press Canada

[3]. Anderson, L.W \& David, R. K. (2015). Kerangka Landasan untuk Pembelajaran,Pengajaran dan Asesmen. Terjemahan: Prihantoro. Yogyakarta: Pustaka Pelajar.

[4]. Arnyana, I. B. P. (2005). Pengembangan Perangkat Model Pembelajaran Berdasarkan Masalah di Pandu Strategi Kooperatif serta Pengaruh Implementasinya terhadap Kemamampuan Berpikir Kritis dan Hasil Belajar Siswa SMA pada Pelajaran Ekosistem. Disertasi, Program Pascasarjana. Samarinda: Universitas Mulawarman

[5]. Atika, S., Isnaini, W., dan Prasetyo, A. P. B. (2012). Pengaruh Pendekatan Problem Based Learning dalam Materi Pencemaran Lingkungan terhadap Kemampuan Analisis. Jurnal of Biology Education, 1 (3), 219-227.

[6]. Aunurrahman. (2009). Belajar dan Pembelajaran. Bandung: Alfabeta

[7]. Awan, R. U. N., Hussain, H., \& Anwar, N. (2017). Effects of Problem Based Learning on Students' Critical Thinking Skills, Attitudes towards Learning and Achievement. Journal of Educational Research, 20 (2), 29-41

[8]. Bilhuda, T., Rusijono., \& Subroto, W. T. (2017). Pengaruh Penerapan Model Problem Based Learning dalam Meningkatkan Aktivitas dan Hasil Belajar Pada Pembelajaran IPS Siswa Kelas V Sekolah Dasar. Jurnal Review Pendidikan Dasar: Jurnal Kajian Pendidikan dan Hasil Penelitian, 3 (20), 439-450

[9]. Daryanto \&Tasrial. (2012). Konsep Pembelajaran Kreatif. Yogyakarta: Gava Media

[10]. Depdiknas. (2003). Undang-Undang No. 20 tentang Sistem Pendidikan Nasional. Jakarta: Departeman Pendidikan Nasional

[11]. Dostal, J. (2015). Theory of Problem Solving. Procedia Social and Behavioral Science, 174, 27982805

[12]. Durotulaila, A. H., Masykuri, M., \& Mulyani. (2014). Pengaruh Model Pembelajaran REACT (Relating, Experiencing, Applying, Cooperating, Transfering) Dengan Metode Eksperimen dan Penyelesaian Masalah Terhadap Prestasi Belajar Ditinjau dari Kemampuan Analisis Siswa. Jurnal Pendidikan Kimia (JPK), 3 (4), 66-74.

[13]. Farida, Lilik. (2010). Penerapan Model Pembelajaran Problem Based Learning Untuk meningkatkan Motivasi dan Aktivitas Belajar di SMA Negeri 2 Malang. Tesis tidak diterbitkan. Malang: Universitas Negeri Malang 
[14]. Firdaus, Aleena Khoeru. (2016). Contoh Identifikasi, Analisis dan Rumusan Masalah [Pesan web log]. Diperoleh dari https://dpendidikan.blogspot.com/2016/04/contoh-identifikasianalisis-dan.html

[15]. Fogarty, R. (1997). Problem Based Learning and Other Curriculum Model for the Multiple Intlegences Classroom. Arlington Height, Illionosis: IRI/Sky Light Training and Publishing, Inc.

[16]. Gunansyah, Ganes. 2015. Pendidikan IPS: berorientasi Praktik yang Baik. Surabaya: Unesa University Press

[17]. Hair, J. F., Black, W. C., Babin, B. J., \& Anderson, R. E. (2010). Multivariate Data Analysis (7th Edition ed.). New Jersey: Pearson Prentice Hall

[18]. Hallinger, P. \& Bridges E. M. (2016). A systematic review of research on the use of problem-based learning in the preparation and development of school leaders. Educational Administration Quarterly, 53 (2), $1-34$

[19]. Hosnan, M. (2014). Pendekatan Saintifik dan Kontekstual dalam Pembelajaran Abad 21 Kunci Sukses Implementasi Kurikulum 2013. Bogor: Ghalia Indonesia

[20]. Huda, Miftahul. (2014). Model - Model Pengajaran dan Pembelajaran. Yogyakarta: Pustaka Pelajar

[21]. Ibrahim, M. \& Nur, M. (2000). Pengajaran Berdasarkan Masalah. Surabaya: Unesa University Press.

[22]. Jihad, Asep \& Abdul Haris. (2012). Evaluasi Pembelajaran. Yogyakarta: Multi Pressindo

[23]. Johnson, D. W., \& Johnson, R. T. (1991). Learning Together and Alone: cooperative, and Individualistic. Third Edition. Engelwood Cliffs, New Jersey: Prentice Hall

[24]. Kowiyah. (2012). Kemampuan Berpikir Kritis. Jurnal Pendidikan Dasar, 3 (6), 175-179

[25]. Kurniasih, Imas dan Sani, Berlin. (2015) Ragam Pengembangan Model Pembelajaran untuk Peningkatan Profesionalitas Guru. Yogyakarta: Kata Pena

[26]. Laksono, W, Endang, Rohaeti, Eli, Suyanta \& Irwanto. (2017). Instrumen Penilaian Kemampuan Berpikir Analitis dan Keterampilan Proses Sains Kimia. Jurnal Kependidikan, 1 (1), 100-110.

[27]. Majid, Abdul.(2009). Perencanaan Pembelajaran. Bandung: Remaja Rosda Karya

[28]. Miller, M. D. (2009) Measurement and Assessment in Teaching. New Jersey : Pearson Education Ltd.

[29]. Ngalimun. (2016). Strategi dan Model Pembelajaran. Yogyakarta: Aswaja Pressindo.

[30]. Nupiksani, Sri. (2015). Meningkatkan Hasil Belajar IPS melalui Penerapan Model Pembelajaran Group Investigation Pada Siswa kelas VI SDN Rejoagung 01 Kecamatan Semboro Kabupaten Jember. Pancaran, 4 (4), 13-24

[31]. Nurhadi. (2004). Pembelajaran Kontekstual dan Penerapannya Dalam KBK. Malang: UM Press.

[32]. Nur, Mohamad. (2011). Model Pembelajaran Berdasarkan masalah. Surabaya: Unesa University Press
[33]. Nur, M. \& Wikandari, P. R. (2000). Pengajaran Berpusat Kepada Siswa dan Pendekatan Konstruktivis dalam Pengajaran. Surabaya: Unesa University Press.

[34]. Parwata, Ida Bagus. (2009). Pengaruh Pembelajaran Berbasis Masalah Terhadap Motivasi Berprestasi dan Hasil Belajar Matematika Pada Siswa Kelas VIII SMP Negeri 1 Banjar. Tesis, Program Pascasarjana. Singaraja: Universitas Pendidikan Ganesha.

[35]. Pardjono dan Wardaya. (2009). Peningkatan Kemampuan Analisis, Sintesis, dan Evaluasi Melalui Pembelajaran Problem Solving. Cakrawala Pendidikan, 8 (3), 257-269. DOI: https://doi.org/10.21831/cp.v3i3.303

[36]. Purwanto, Ngalim. (2006). Prinsip-Prinsip dan Teknik Evaluasi Pengajaran. Bandung: Remaja Rosda Karya

[37]. Riyanto, Yatim. (2007). Metodologi Penelitian Pendidikan Kualitatif dan Kuantitatif. Surabaya: Unesa University Press.

[38]. Ruseffendi. (2005). Dasar - Dasar Penelitian Pendidikan \& Bidang Non-Eksata Lainnya. Bandung: Tarsito

[39]. Rusman. (2012). Model-Model Pembelajaran. Jakarta: PT. Rajagrafindo Persada.

[40]. Rusman. (2014). Penerapan Pembelajaran Berbasis Berbasis Masalah. Edutech, 1 (2), 211-230

[41]. Rusmono. (2012). Strategi Pembelajaran dengan Problem Based Learning Itu Perlu. Bogor: Ghalia Indonesia.

[42]. Sapriya. (2009). Pendidikan IPS Konsep dan Pembelajaran. Bandung:PT Remaja Rosdakarya.

[43]. Şimşek, Y. (2017). The Evaluation of the Application of Transported Education by Teachers. International Journal of Educational Research Review, 2 (1), 4148. DOI: https://doi.org/10.24331/ijere.309972

[44]. Smitha, E. T. \& Aruna, P. K. (2014). Effect of Science Technology Society Approach on Achievement Motivation in Biology of Secondary School Students of Kasaragod District. IOSR Journal of Humanities and Social Science, 19 (4), 54-58

[45]. Sugiyono. (2016). Metode Penelitian Kuantitatif, Kualitatif dan $R \& D$. Bandung: PT Alfabet

[46]. Sugono, Dendy. (2008) Kamus Besar Bahasa Indonesia Edisi Keempat. Jakarta: PT. Gramedia Pustaka Utama

[47]. Suhana, Cucu. (2012). Konsep Strategi Pembelajaran. Bandung: Refika Aditama

[48]. Suhanadji dan Subroto, Waspodo Tjipto. (2003). Pendidikan IPS. Surabaya: Insan Cendekia.

[49]. Sunaryo, Yoni. (2014). Model pembelajaran Berbasis Masalah Untuk Meningkatkan Kemampuan Berpikir Kritis dan Kreatif Matematika Siswa SMA di Kota Tasikmalaya. Jurnal Pendidikan dan keguruan, 1 (2), pp. 43.

[50]. Sundayana, Rostina. 2012. Statistika Penelitian Pendidikan. Bandung : Alfabeta

[51]. Trianto. (2007). Model - Model Pembelajaran Inovatif Berorientasi Konstruktivisme. Jakarta: Prestasi Pustaka Publisher.

[52]. Trianto. (2007). Model Pembelajaran Terpadu Dalam Teori dan Praktek. Jakarta: Prestasi Pustaka Publisher. 
[53]. Trianto. (2010). Model Pembelajaran Terpadu, Konsep, Strategi dan Implementasinya dalam KTSP. Jakarta: Bumi Aksara.

[54]. Usman, M. U. (2002). Menjadi Guru Profesional. Bandung: PT. Remaja Rosdakarya.

[55]. Wena, Made. (2009). Strategi Pembelajaran Inovatif Kontemporer: Suatu Tinjauan Konseptual Operasional. Jakarta: PT. Bumi Aksara

[56]. Wiguna, F. A., \& Damayanti, S. (2018). Pengaruh Model Pembelajaran Berbasis Masalah Terhadap Kemampuan Berpikir Kreatif Siswa Pada Pembelajaran IPS Di SDN Ngadirejo Kota Kediri. Jurnal Pendidikan Dasar Nusantara, 3 (2), 175-188

[57]. Yamin, Martinis. (2007). Profesionalisasi Guru \& Implementasi KTSP. Jakarta: GaungPersada Press.

[58]. Yulianti, E., Rosani, M., \& Nuranisa. (2018). Pengaruh Model Pembelajaran Problem Based Learning Terhadap Kemampuan Berpikir Analitis Siswa SSM Negeri 2 Banyuasin 1. Jurnal Swarnabhumi, 3 (2), 89-93. 